\title{
Research Article: Bio availability of iron from finger millet, pearl millet and rice (control) recipes
}

\author{
M. MOUNIKA, K. UMA DEVI AND S. SUCHARITHA DEVI
}

Article Chronicle : Received : 17.07.2017;

Accepted :

01.08.2017

Key Words:

Bioavailability of iron, Finger millet, Pearl millet, Rice

Author for correspondence :

\section{MOUNIKA}

Department of Foods and Nutrition, Post Graduate and Research Centre, Professor Jayashankar Telangana State Agricultural University,Rajendranagar, HYDERABAD (TELANGANA) INDIA

Email: mounikejiya

@gmail.com
SUMMARY : The present study entitled "Bioavailability of iron from finger and pearl millet based recipes" was conducted on four millet preparations namely dosa, idli, roti and rice (meal), using two millets namely finger millet, pearl millet. The iron content of millets was 3.65, 7.0mgin finger millet, pearl millet, respectively. Compared to rice all millets had high amount of protein, fat, ash and iron content, while the carbohydrate was low in millets compared to rice. Wheat had similar protein, fat and carbohydrates close to many types of millet.The total iron was good in all preparations.Finger millet idli had $4.57 \mathrm{mg}$ and meal had $4.58 \mathrm{mg}$ total iron without any significant difference between the two products. The dosa had a total iron of $5.04 \mathrm{mg}$ and roti had $5.55 \mathrm{mg}$ both of which differed significantly compared to each other and with other preparations $(\mathrm{p}<0.05)$. Per cent available iron was highest in finger millet dosa at $37.3 \%$ against $4.1 \%$ in idli, $12.3 \%$ in roti and $2.7 \%$ in meal with significant difference between each other $(\mathrm{p}<0.05)$.Per cent available iron was highest in pearl millet dosa at $62.4 \%$ against in $33.5 \%$ in idly, $44.0 \%$ in roti and $44.0 \%$ in meal. Total iron content was $7.9 \mathrm{mg}$ in rice dosa, which was highest, followed by $4.8 \mathrm{mg}$ in roti, $3.8 \mathrm{mg}$ in meal and $1.8 \mathrm{mg}$ in idli, with significant difference between preparations ( $\mathrm{p}<0.05)$.Per cent available iron was least in roti at $5.2 \%$ against meal at $8.2 \%$, idli at $6.59 \%$ and dosa at $25.6 \%$ with significant difference between each other. Percent available iron was least in roti at $5.2 \%$ against meal at $8.2 \%$, idli at $6.59 \%$ and dosa at $25.6 \%$ with significant difference between each other. The in vitro availability of iron was high in dosa, probably due to fermentation and shallow fry on iron tawa, seems to low steamed cooking method of pearl millet idly compared to dry heat or roasted millet preparations.

How to cite this article : Mounika, M., Devi, K. Uma, Devi, S. Sucharitha (2017). Bio availability of iron from finger millet, pearl millet and rice (control) recipes. Agric. Update, 12(TECHSEAR-6) : 1484-1490; DOI: 10.15740/ HAS/AU/12.TECHSEAR(6)2017/1484-1490. 